\title{
Religious slaughter in European union - Short review
}

Martin Dobeic

\begin{abstract}
The aim of this paper was to review current religious slaugtering processes and dillemas in EU. Stunning of animals before slaughter is a legally prescribed requirement in the EU intended to reach animal unconsciousness so that slaughter does not cause anxiety, pain, suffering or distress. In some European Union countries, religious slaughter is exceptionally allowed without stunning. Animals intended for religious slaughter must be healthy and undamaged. In order to meet these requirements, religious slaughtering in the EU is being implemented only in allowed and approved slaughterhouses. Slaughter can only be performed by authorized and educated operators. Regarding religious slaughter, there are many dilemmas in the EU about whether this methods of slaughter causes additional suffering of animals. Insofar as Muslim slaughter in some cases allows some methods of the preslaughter stunning, Jewish slaughter does not allow any stunning. Therefore, it is necessary to take into account the fact that in the future, it will be necessary to examine alternative stunning methods which will ensure the integrity of live animals before bleeding. At the same time, it is necessary to harmonize the guidelines for a harmonized procedures of handling animals before and after slaughtering and certifying of the meat originating from religious slaughter in order not to mislead consumers.
\end{abstract}

Key words: religious slaughter, stunning, EU

\section{INTRODUCTION}

The slaughter of animals is closely defined in European Union (EU) legislation, with the basic requirement of animal stunning before bleeding. The Council of Europe Convention for the Protection of Animals for Slaughter (Council of Europe, 1979) and Council Regulation (EC) No 1099/2009 (The Council of the European Union, 2009) provide that animals must be stunned before slaughter (Devos et al., 2018, Ferraro, 2014, The Law Library of Congress, Global Legal Research Center, 2018). The legislation also determines the rules concerning standard operating procedures (SOP) in slaughterhouses, the de- termination of the person responsible for the welfare of the animals and the qualifications of staff who handle and slaughter the animals. Legislation also covers the aspects of slaughter procedures outside of slaughterhouses, farmed game animals and religious slaughter (European Commission, 2015). In the case of religious slaughter, the legislation allows the exceptions, which means that when religious slaughter of animals is carried out, legislation allows the slaughter without prior stunning (Shechita UK, 2009, FAO 2018, Miele, 2016). Regarding the mentioned provisions of EU legislation, the religious authority operates under the supervision of the

\footnotetext{
1 *Martin Dobeic. PhD, associated professor, University of Ljubljana, Veterinary Faculty, Institute for Food Safety, Feed and Environment, Department for Environment and Animal Nutrition, Welfare and Hygiene, Gerbičeva 60, SI-1000 Ljubljana, Slovenia;
}

Corresponding author: martin.dobeic@vf.uni-lj.si 
official veterinarian of the EU Member State, as set out in Regulation 1099/2009. EU Member States are allowed to decide on the possibilities of religious slaughter for themselves, and they also decide on the import and/or export of meat slaughtered in the religious slaughter (Velarde et al., 2014).

Ritual slaughter is an act in which animals are slaughtered according to the manner required by a certain religion. Because ritual slaughter takes into account religious principles, it can also called religious slaughter. Religious slaughter is mainly intended to provide meat suitable for the food of religious (in the EU predominantly Muslim and Jewish) population; however it can also be dedicated to some feasts, for example Islamic Feast of Sacrifice (Schyff, 2014). Religious slaughter in the EU is aimed primarily for religious communities to justify their identity, which can reconnect with their original culture also with traditional food and nutrition practices. Taking in the consideration that by some estimations the growth of the Muslim population will increase to 8.3 billion by the year 2030, what means $26.4 \%$ of the entire world population, the fact is that the abundance of Muslim populations will increase also in the EU, therefore the halal meat market is constantly increasing (Miele, 2016).

Nonetheless, the religious beliefs, that make these practices, may be opposed to the local public opinion that advocate the slaughter of animals with prior stunning, which does not cause unnecessary suffering to the animals. In such cases, the divergence and cultural diversity of religious communities are under pressure, and the public opposition to multiculturalism can also arise. The public's dilemmas regarding slaughter without prior stunning or with post-cut stunning are reflected in particular from the point of view of animal suffering during incorrect and uncontrolled religious slaughter in unauthorized slaughterhouses without proper veterinary examination of animals, as well as inadequate handling of animals. Therefore many EU countries restrict or even prohibit slaughtering without stunning and among the other also due to possible excessive commercialization of products of religious slaughter. (Kurth et al., 2015).

For religious slaughter, special permits are needed, on the basis on the local community needs for meat consumption (Miele, 2013). Religious slaughter can only take place in specially organized approved slaughterhouses and is carried out only by persons with the necessary knowledge and skills. Religious slaughter can be carried out exclusively in the presence of a state veterinarian responsible for the slaughter and inspection of meat. Slaughter without prior stunning can only be carried out with the equipment to ensure that the animals are placed in the position necessary for religious slaughter. Slaughter is performed by opening large blood vessels in the throat area with a single cut (The Law Library of Congress, Global Legal Research Center, 2018).

\section{MUSLIM AND JEWISH RELIGIOUS SLAUGHTER}

The Muslim method of slaughter is called Dhabh or Zabiha to produce Halal meat, while the Jewish method is called Schechita, to produces meat labeled Kosher (Hewson, 2012, FAO, 2018). Religious slaughter, as a practice of meat production mainly for Islamic and Jewish consumers, is based on a complex set of rules where the neck of the stunned animal is cuted with a sharp knife, leading to massive bleeding (Kurth et al., 2015). In principle in both methods of animal slaughter animals are killed without prior stunning. While in some countries, some forms of stunning may be allowed in Muslim methods of slaughter, stunning is not permitted in the Jewish methods (Salamano et al., 2013).

In principle in both methods the bleeding is caused by a religious knife with exceptional sharpness, cleanliness, of a certain width and length, with the single long cut of trachea, throat and neck, so that the skin does not cover the surface of the blade (Nakyinsige et al., 2013, Anil, 2013).

\section{THE SITUATION OF THE RELIGIOUS SLAUGHTER IN EUROPEAN COUNTRIES}

Many European countries as Sweden, Norway, Iceland, Denmark and Slovenia do not allow slaughter without prior stunning (Miele, 2016). In Switzerland and Lichtenstein pre-stunning is required with exception for poultry. In Finland, pre-stunning is required but an exception is granted for religiously slaughtered animals which are stunned at the same time as the cut of the neck and start of bleeding, thus in practice, in Finland halal slaughter is done only by pre-stunning. In Belgium, religious slaughter is not prohibited at the federal level, but two of the three Belgian regions (Wallonia, Flanders) have recently adopted the legislation that prohibits these practices and requires prior stunning. The legislation will come into force in 2019, unless this would trigger a constitutional dispute. In some countries, including Austria, Estonia, Greece and Latvia, religious slaughter is permissible insofar as animals are stunning in post-cut (Salamano et al., 2013).

Cyprus, Spain, France, Germany, Poland, Luxem- 
bourg, the Netherlands and Croatia allow religious slaughter by various forms of regulation (The Law Library of Congress, Global Legal Research Center, 2018, Uršulin-Trstenjak et al., 2015). For example, in Germany and in the Netherlands, religious slaughter is allowed only for the needs of local religious communities, while the export of such meat is prohibited (Schyff, 2013, Miele, 2016).

On the other hand, due to demand and trade in the international market, some countries have adopted their own Halal standards. Croatia, Bosnia and Herzegovina, Serbia, Montenegro and FYR of Macedonia adopted Halal certification as BAS 1049: 2010, while Croatia adopted Croatian Standard HRN BAS 1049: 2010 which define the measures that must be fulfilled in accordance with Islamic religious laws (Uršulin-Trstenjak et al., 2015). In Croatia, several companies have a halal certificate. It is interesting, however, that in some countries where religious slaughter is prohibited the import kosher and halal meat is not prohibited (The Law Library of Congress, Global Legal Research Center, 2018). Due to the increased demand for the halal meat and the lack of uniform standards for halal meat, the EU financed the Dialarel project to establish a dialogue on religious slaughter between the science and religion of the Jewish and Muslim citizens in Europe. The project was based on the unification of social and natural sciences with the aim of developing and unifying the methods and guidelines for assessing the animal welfare at the time of slaughter (Miele, 2013).

As regards religious slaughter, many debates arise reagarding the stress of animals during the pre-slaughtering period, about the pain during the neck cut and the length of period in which animals become unconsciousness after cut. Concerning the first question, for example the problem of tying legs in traditional forms of slaughter, or back position of animals during shechita slaughter procedure can be exposed. As well the pain during the neck cut is scientifically proven and lasts from 10 to 120 seconds before animals fall into unconsciousness, in addition, blood clots, and carotid occlusions (aneurysms) can cause a slower loss of blood and consequently the late occurence of animal unconsciousness (Anil, 2013).

\section{WHAT IS DHABIHA (ZABIHA) (HALAL MEAT)}

Halal is an Arabic word and means a system of admissibility in Islam (Anil, 2013). Sharia legislation defines that all the acts or certain products that are permitted in daily life are halal, while those that are prohibited are haram. Anything that does not belong to the haram or halal belongs to the category of dubious-mushbooh. If the halal is applied in relation to meat, certain requirements must be met in order to ensure the conditions for the certification of halal meat quality. In the first place, this is the meat of animals that are raised under certain conditions according to Islamic scriptures (Kuran and Hadith), and the consumption of this meat is a religious act (Fuseini et al., 2014, Uršulin-Trstenjak et al., 2015).

The Islamic way of killing animals for meat is called Dhabiha (Zabiha). Muslim slaughter (AlDhabh) is allowed in the name of the God, so the operator recites Tasmiyah within the slaughter act, which is the neck cut, reminding that he takes the life of a living being. (Anil, 2013, Miele, 2016).

Slaughter must be carried out under certain conditions in which the animals are bleeding to death, The blood must be thrown away while it is inedible for the Muslims, thus it is haram. Slaughter can only be carried out by educated and accredited Muslim staff. Halal slaughter does not normally include pre-stunning of the animals, although some Muslim communities permit the stunning if the method of stunning does not damage the skulls. Therefore, exceptionally before, or during the slaughter, a stunning method with an electric stunning (electric claws for cattle, sheep and goats and an electric water bath for poultry) can be used. Reversible electrical stunning does not damage the integrity of animal. Low voltage electrical currents in high frequencies are used that do not kill animals $(>100 \mathrm{~Hz})($ Anil, 2013). However, it is important that in the case of the electrical stunning, two operators have to cooperate in the act of slaughtering. The first operator stun the animal with electric clamps, and the other has to cut the neck immediately after effective stunning. Namely, insensitivity of animal stunned by electrical stunning takes only a short time - for example, in cattle only for a period of 31 to 90 seconds (Salamano et al., 2013).

Islam has adopted the rules for humane slaughter of animals, starting with the correct handling with animals on the transport, keeping animals healthy before slaughter, and managing the act of slaughter with a matured Muslim who has healthy spirit, and fully understand the Islamic procedure and conditions for slaughtering animals (Salamano et al., 2013).

The procedure of slaughtering have to be carried out only on one individual animal (Fuseini et al., 2014, FAO, 2018). Halal process of animal slaughter involves holding, stunning (if used) and cutting the trachea, esophagus and both carotid arteries and jugular veins. Animal restraint must be unstressfull, because stress methods can cause 
injury and consequently animal suffering (Nakyinsige et al., 2013). Animals have to be slaughtered with an appropriate long and sharp knife, which cuts the trachea and neck vessels with one stroke. Animals are slaughtered individually with necessary care (Aidaros, 2013, Humane Slaughter Association, 2016).

\section{WHAT IS SHECHITA (KOSHER MEAT)}

Meat suitable for the food of the Jews is called kosher (Anil, 2013); unsuitable meat is trifah. Shechita is a Jewish religious method of slaughtering animals for the production of kosher meat (Miele, 2016).

Animals intended for slaughter by kosher method must come from animal-friendly breeds. Jewish religious legislation requires that animals before slaughtering have to be healthy, not hurt and they not suffer during the slaughter (Humane Slaughter Association, 2016, Shechita UK, 2009, Pozzi et al., 2015, Salamano et al., 2013, Zivotofsky, 2011).

Owing to this demand, Shechita is performed with a surgically sharp knife (kalafa), which is estimated to be twice longer (cca $40 \mathrm{~cm}$ for cattle) as the diameter of the animal neck. Before the cut animals have to be appropriately fixed with the exposed neck (for example, the sheep are placed on the back, the cattle neck is exposed by the head layed on the chin, rotary fixation boxes enable to turn the animals onto their backs). The knife should be examined after each cut. The cut must be carried out without interruption and without pressure on the neck and vessels; the knife must be visible from beginning to the end of cut (Anil, 2013). The cut is performed with a single rapid cross-section of the trachea, esophagus, carotid arteries, and the jugular veins, whereby it must not be as deep as to touch the spine. Such cut should cause an immediate drop in the blood pressure in the brain, because the blood loss is very rapid, while the animal losing up to $1 / 3$ of the total amount of blood in 30 seconds (Zivotofsky, 2011). Shechita can only be carried out by qualified and accredited Jud Shochetim, who performs special training and obtains the permission for slaughter of the main rabin in the country ( $\mathrm{Ai}$ daros, 2013, Humane Slaughter Association, 2016, Zivotofsky, 2011). Shochetim needs to be educated in a few years long study named yeshiva (advanced religious seminars). The training also includes practical aspects of slaughtering and examination for the tififa (rejected parts). It is especially important to remove the blood from the carcass, the sciatic nerve and some of the fat of the back of the animal, otherwise the meat is not useful. These parts of animal are removed by specially trained experts, called "porger", or "treiber" (Anil, 2013).

The slaughter of shechita must be carried out exclusively without the prior stunning of animals and is an integral part of Jewish law (Talmud). Jews are prohibited to consume other meat than meat obtained by the Shechita method, despite the fact that Jewish religious legislation emphasizes the animal protection, minimising the suffering and welfare of animals, and opposes to the inhuman exploitation of animals such as bullfighting, sports hunting etc. The Jewish method of slaughter is controlled by the Shechita Committee, which licenses and performs regular inspections of shochtim, bodeks and porgers, including mandatory testing of knife (Humane Slaughter Association, 2016, Shechita UK, 2009, Pozzi et al., 2015, Zivotofsky, 2011).

\section{DILEMMAS REGARDING RELIGIOUS SLAUGHTER}

Discussions and dilemmas regarding religious slaughter without prior stunning are mainly focused on the welfare of animals (Hewson, 2012, FAO, 2018, Fuseini et al., 2017, Sabuncuoglu and Coban, 2008). If in some cases Islamic slaughter still allows some forms of stunning, the Jewish method of slaughter, does not permit stunning before slaughter (Szumigalska and Bazan, 2014, Novelli et al., 2016). The Jewish authorities argue that due to the sharpness of the knife, the animal does not feel any pain and, because of the rapid loss of blood, they believe that animals are insensitive after few seconds (Aidaros, 2013, Humane Slaughter Association, 2016).

Royal Society for Preventing Cruelty on Animals (RSPCA) argues that religious slaughter without stunning is "unnecessary suffering of animals" (Barclay, 2011). By some studies the unconsciousness of the animals, after the cross-section of the veins and the trachea does not occur immediately, but only after approx. 20-60 seconds (depending on the animal species - $90 \%$ of cattle lose consciousness after 17 seconds, sheep after 14 seconds (Hewson, 2012). The second study found that the rhythmic breathing of the lambs disappeared after 44 seconds. The corneal reflex disappeared at 116 seconds, the heart rate was increased, which may be the result of the haemorrhagic shock, the unconsciousness of tested lambs occurred not until 1 minute after cut (Rodriguez et al., 2012).

This raises the question to what extent animals are suffering from pain, stress, anxiety and weaknesses that occur when the neck is cut, due to the limitation and the unnatural position of the body (on the side or on the back), and due to lower blood pressure and lack of blood in the brain (Aidaros, 
2013, Humane Slaughter Association, 2016, Ferraro, 2014, Barclay 2011).

On the other hand, as a result of the cross-section of the cervical vessels, aspiration of the blood into the trachea and the respiratory tract results in pain and the formation of false aneurysms at the ends of the cutted carotid arteries, which slow down the bleeding of the animals and consequently to longer period to unconscious of animals. The time in which the animal loses consciousness also depends on the fact that the vertebral arteries continue to supply blood to the brain, which further contributes to the delayed loss of consciousness. Research also suggests that the occurrence of false aneurysms is less likely if the neck is cutted at the level of the first cervical vertebra, and not between the second and fifth vertebrae, where the neck is usually cutted in the religious slaughter (Hewson, 2012). In addition, the neck section according to scientific findings reliably causes pain, since the neck tissues contain nociceptors (Humane Slaughter Association, 2016). Measurements of electrical activity in the brain have shown that the throat cut show signs of pain that disappear as soon as the animal is stunned (Barclay, 2011).

However, in order to minimize pain during religious slaughter, its rules dictate that animals have to be fixed by special restrainers, especially the head and neck. Animals, as long as they are conscious, must not be tied and raised, which could cause the additional stress (FAO, 2018).

The question of whether religious slaughter is more or less humane than the other methods of slughter is the issue of debates (Schyff, 2013). Namely also the allowed and prescribed pre-slaughter stunning methods are not completely reliable methods for achieving the insensitivity of animals and has many failures. It is interesting to note that animals must be unconscious in 200 milliseconds, otherwise they may feel the stunning effect, while stunning must be carried out professionally and with appropriate equipment (Hewson, 2012, Pozzi et al., 2015). On the other side there is a question regarding the quality of the meat gained by conscious slaughter and slaughter after or following the stunning. The results of some studies have shown that, for example, when slaughtering of goats is performed without stunning, or stunning is performed after cut (post-cut stunning), there is no difference in bleeding and meat quality (Sabow et al., 2015, D'Agata et al., 2009, Fuseini et al.,2016). The results of other studies show the opposite. The $\mathrm{pH}$ value of calves was lower in meat from conventional sla- ughter than from religious slaughter. Probably the absence of stunning prolonged the suffering of the animals and therefore led to a reduction in muscle glycogen and, consequently, an increase in $\mathrm{pH}$ and thus a risk of increasing microbial growth and consequently the decrease in meat quality and shelf life. On the other hand, the meat of calves slaughtred without stunning dropped less than the meat of stunned calves what can be explained by increased water retention capacity in the meat of unstunned calves which is resulted from a higher $\mathrm{pH}$. However, meat of unstunned calves showed significantly more petechial bleeds which is associated with the stress and consequently higher blood pressure (D'Agata et al., 2016). Due to all of the above, there are considerable dilemmas about the suffering of animals at religious slaughter (Zuolo, 2015).

Despite the fact that conventions, directives and regulations in EU formally permit religious slaughter, taking into account the freedom to express religious belief in worship, teaching, practice and respect in accordance with Article 10 of the Charter of Fundamental Rights of the European Union, religious slaughter in the EU is still an example of a moral conflict, which has recently been shaped into a principled ethical dilemma if human religious freedom should be considered more than animal welfare (Ferraro, 2014, Zuolo, 2014, Zuolo, 2015). On the one hand, there is widespread moral concern for the lowest suffering of sentient beings; on the other hand, it is a legitimate concern about human freedom, more precisely freedom of expression, religious beliefs and the formation of one's own life in accordance with such beliefs (Ferraro, 2014). For this reason, for example, in Germany Halal slaughter and the Hebrew Shechita have already been recognized as legitimate in terms of constitutional fundamental rights on the freedom of religious expression (Zivotofsky, 2011). At the same time, some Islamic authorities agreed with some stunning methods that do not harm the body and the brain of animals which allow rapid reversible awareness (Ferraro, 2014). Countries like Saudi Arabia, United Arab Emirates (UAE), Indonesia, Malaysia, Singapore, Egypt, Kuwait and Yemen accepted the stunning of animals before slaughter. Fatwa, published by the Egyptian Fatwa Council at Al Azhar University in 1978, was specially designed to confirm the suitability of electric stunning for halal slaughter. Fatwa, issued in 1987 by the 10th Fiqh Council in Makkah, in the World Muslim League, which took place from 24 October to 28 October 1987 in Saudi Arabia, was issued regarding to acceptance of reversible 
electric stunning. Fatwa, which was issued in 2006 by the Judicial Council in Yemen, was also issued regarding the reversible electric stunning. All Fatwa emphasize the reversibility of stunning.

Regarding the doubts whether the animals remain alive after stunning, as well as problems in identifying actually living animals, the performance of bleeding and the quality of meat, there are still many who encourage halal slaughter without stunning. Thus in identifying live animals after stunning, Halal Certification Bodies (HCB) rely on the presence of animals movement, heartbeat, and ability to bleed. Unfortunatelly none of these signs is absolute proper as indicator for a definition of a live animal. It has been established that reflexes are still present even after the death of the brain and the heart can beat for some time also after the death of the brain due to the presence of remaining oxygen in the musculature. Also the ventricular fibrilation caused by irreversible stunning, can blur the signs of namely living animals and in addition also the bleeding does not depend solely on the pumping ability of heart. An even bigger problem arises in poultry, which is stunned with an electric bath, in which the electric current flows through the whole animal, not only over the head. In higher electro-conductive animals electrical stunning can lead to a heart failure and the death of animal (Fuseini et al., 2016).

\section{STANDARDS AND TRADE IN MEAT HALAL}

The EU market with the meat of religious slaughter origin is in expansion. Initially, the market was mainly running in ethnic shops; however today it is possible to buy halal meat also in shopping centers and restaurants (Lever et al., 2012). Most halal meat is sold in the UK and France and recently in Germany, while market is mainly increasing on the account of the rising number of Muslim population. In addition, in many cases the question about the authenticity of the origin of the halal meat is arising on the last time. In some Halal products, even the presence of pork meat or at least the pig DNA (Fuseini et al., 2017) was found. The reason for this is in the fact that due to the market economy and unfair competition and the desire for higher earnings, many slaughterhouses, which normally carry out the slaughter of pigs, also perform the religious slaughter of cattle (Fuseini et al., 2017). In addition, there is an increasing lack of transparency in the supply chain of meat from religious slaughter. For example, parts of the carcasses that do not conform to halal can easily come into the market, mixing of the meat even with pork can happen, cross-contamination of halal meat with non halal meat is very plausible (Miele, 2016).

For this reason, halal meat certification in Europe is very important today and in the future. The aim of the certification is to ensure the originality of the animal husbandry practices from farming to slaughter, slaughter procedures and the proper labeling of products (Pointing et al., 2008). At the same time, the certification goal is also to unify the rules for obtaining certificates. Namely, the certificate can now be obtained only for meat of an animal that was stunned or not, depending on the certification authority in the country. In addition, certificates will certify that the animal was still alive at the time of slaughter (Miele, 2016, Pointing et al., 2008).

At the same time, the quality of the food labeled halal is also linked to the Tayyib concept, which is based on healthy and safe foods, thus even Halal-Tayyib food production is proposed (Fuseini et al., 2017).

\section{CONCLUSIONS}

Religious slaughter in the EU is a fact. It is likely that discussions on the ethical aspects of religious slaughter will continue, many of which will be the subject of constitutional disputes in the future thus there are still differences between the EU countries regarding the acceptance of religious slaughter. It is certainly necessary to go beyond in research in the direction of introducing new alternative methods that would keep the integrity of animals and would replace the current forms of stunning (for example, calming pheromones or sedatives), keeping the required Jewish and Muslim slaughtering methods (Miele, 2013).

\section{REFERENCES}

Aidaros, H. (2013): Proper Application for Halal Slaughter. 12th Conference of the OIE Regional Commission for the Middle East Amman (Jordan) 23-26 Sep. 2013. http://citeseerx.ist.psu.edu/viewdoc/download?doi=10.1.1.636.5033 \&rep=rep1\&type=pdf (oct.2018)

Anil, H. M. (2013): Effects of slaughter method on carcass and meat characteristics in the meat of cattle and sheep. EBLEX and AHDB, 1-73. http://beefandlamb.ahdb.org.uk/wp/ wp-content/uploads/2013/04/slaughter_and_meat_quality_ feb_2012-final-report.pdf (oct. 2018)

Barclay, C. (2011): Religious Slaughter. https://humanism.org.uk/wp-content/uploads/sn01314.pdf (oct. 2018)

Council of Europe (1979): European Convention for the Protection of Animals for Slaughter. European Treaty Series No. 102, 7 p. https://rm.coe.int/1680077d98 (oct. 2018)

D'Agata, M., C. Russo, G. Preziuso (2009): Effect of Islamic Religious slaughter on beef quality. Ital.J.Anim. 
Sci.8(2),489-491.https://www.tandfonline.com/doi/ pdf/10.4081/ijas.2009.s2.489 (oct.2018)

The Council of the European Union (2009): COUNCIL REGULATION (EC) No 1099/2009 of 24 September 2009 on the protection of animals at the time of killing. Official Journal of the European Union L 303/1. https://eur-lex.europa.eu/ LexUriServ/LexUriServ.do?uri=0J:L:2009:303:0001:0030:EN: PDF (oct. 2018)

Devos, G., C. P. H. Moons, K. Houf (2018): Diversity, not uniformity: slaughter and electrical waterbath stunning procedures in Belgian slaughterhouses. Poultry Sci., 97(9), 33693379. https://academic.oup.com/ps/article-abstract/97/9/33 69/4999969?redirectedFrom=fulltext (oct. 2018)

European Commission (2015): Overview report Animal welfare at slaughter in Member States. Directorate-general for health and food safety. Ref. Ares(2015)4056423 01/10/2015, $21 \mathrm{p}$.

FAO (2018): CHAPTER 7: Slaughter of livestock. http:// www.fao.org/docrep/003/x6909e/×6909e09.htm (oct. 2018)

Ferraro, F. (2014): Religious Slaughtering Vs. Animal Welfare: A Utilitarian Example of (Moral) Conflict Management. Draft. https://ecpr.eu/Filestore/PaperProposal/a676a20d6db7-411f-ab6a-ac29465d6ce9.pdf (oct.2018)

Fuseini, A., T.G. Knowles, P. J. Hadley, S.B. Wolton (2016). Halal stunning and slaughter: Criteria for the assessment of dead animals. Meat Sci 119, 132-137. https://www.sciencedirect.com/science/article/abs/pii/ S0309174016301267 (oct.2018)

Fuseini, A., S. B. Wotton, T. G. Knowles, P. J. Hadley (2017): Halal Meat Fraud and Safety Issues in the UK: a Review in the Context of the European Union. Food Ethics, 1(2), 127 142. https://link.springer.com/article/10.1007/s41055-0170009-1 (oct. 2018)

Fuseini, A., S.B. Wolton, P.J. Hadley, T.G. Knowles (2017): The perception and acceptability of pre-slaughter and post-slaughter stunning for Halal production: The views of UK Islamic scholars and Halal consumers. Meat Sci 123, 143-150. https://www.sciencedirect.com/science/article/abs/ pii/S0309174016303151 (oct.2018)

Hewson, C. (2012): Livestock: Slaughter and Killing Animals for Disease Control

Purposes World Animal Protection, David Main (University of Bristol). Module 16. Lecture Notes. https:// www.globalanimalnetwork.org/sites/default/files/International/Documents/M16_LN_Killing_Disease_Control. pdf (oct. 2018)

Humane Slaughter Association (2016): Religous Slaughter-The facts. https://www.hsa.org.uk/downloads/relateditems/religious-slaughter.pdf (oct. 2018)

Kurth, L., P. Glasberge (2015): Dealing with tensions of multiculturalism: The politics of Religious slaughter in the Netherlands. European Journal of Cultural Studies, 20(4), 413-432. http://journals.sagepub.com/doi/ pdf/10.1177/1367549415603375 (oct. 2018)

Lever, J., M. Miele (2012): The growth of halal meat markets in Europe: An exploration of the supply side theory of religion. Journal of Rural Studies, 28(4), 528-537. https://www. sciencedirect.com/science/article/pii/S0743016712000666 (oct. 2018)

Miele, M. (2013): Religious Slaughter: Promoting a Dialogue about the Welfare of Animals at Time of Killing. Society \& Animals 21, 421-424. http://www.animalsandsociety.org/ wp-content/uploads/2016/05/miele.pdf (oct. 2018)

Miele, M. (2016): Killing Animals for Food: How Science, Religion and Technologies Affect the Public Debate About Religious Slaughter. Food ethics 1, 47-60. https://link.springer.com/article/10.1007/s41055-016-0004-y (oct. 2018)

Nakyinsige, K., Y. B.Che Man, Z. A. Aghwan, I. Zulkifli, Y. M. Goh, F. Abu Bakar, H. A. Al-Kahtani, A.Q.Sazili (2013): Stunning and animal welfare from Islamic and scientific perspectives. Meat Sci., 95(2), 352-361. https://www.sciencedirect.com/science/article/pii/S0309174013001265 (oct. 2018)

Novelli, S., P. Sechi, S. Mattei, M. Francesca lulietto, G. B. T. Cenci (2016). Report on religious slaughter practices in Italy. Veterinaria Italiana, 52 (1), 5-11. http://www.izs.it/ vet_italiana/2016/52_1Netlt_189_920_1.pdf (oct. 2016)

Pointing, J., Y. Teinaz, S. Shafi (2008): Illegal labelling and Sales of Halal Meat and Food Products. The Journal of Criminal Law, 72(3), 206-213. https://journals.sagepub.com/ doi/pdf/10.1350/jcla.2008.72.3.496 (oct.2018)

Pozzi, P.S.,W. Geraisy, S. Barakeh, M. Azaran (2015). Principles of Jewish and Islamic Slaughter with Respect to OIE (World Organization for Animal Health) Recommendations. Israel Journal of Veterinary Medicine. Vol. 70(3), 3-16. http:// www.ijvm.org.il/sites/default/files/prinicples_of_jewish_and_ islamic_slaughter_sept_2015.pdf (oct.2018)

Rodríguez, P., AVelarde, A.Dalmau, P.Llonch(2012): Assessment of unconsciousness during slaughter without stunning in lambs. Animal Welfare, 21(S2) 75-80. https://www.researchgate.net/profile/Pedro_Rodriguez/publication/230701300_ Assessment_of_unconsciousness_during_slaughter_without_stunning_in_lambs/links/0912f50332fe8326ce000000/ Assessment-of-unconsciousness-during-slaughter-withoutstunning-in-lambs.pdf (oct.2018)

Sabow A.B., Q. Sazili, I. Zulkifli, Y.M. Goh, M.Z.A. A. Kadir, N.R. Abdulla, K.Nakyinsig, U.Kaka, K.D. Adeyemi (2015): A comparison of bleeding efficiency, microbiological quality and lipid oxidation in goats subjected to conscious halal slaughter and slaughter following minimal anesthesia. Meat Sci, 104, 78-84. https://www.sciencedirect.com/science/article/abs/pii/S0309174015000418 (oct. 2018)

Sabuncuoglu, N, O. Coban (2018):Attitudes of Turkishveterinarians towards animal welfare. Animal Welfare, 17, 27-33. https://www.researchgate.net/profile/Nilufer_Sabuncuoglu/ publication/263380363_Attitudes_of_Turkish_veterinarians_ towards_animal_welfare/links/56558c5b08aeafc2aabc5040/ 
Attitudes-of-Turkish-veterinarians-towards-animal-welfare. pdf (oct. 2018)

Salamano, G., A. Cuccurese, A. Poeta, E. Santella, P. Sechi, V. Cambiotti, B. T. Cenci-Goga (2013): Acceptability of Electrical Stunning and Post-Cut Stunning Among Muslim Communities: A Possible Dialogue. Society \& Animals 21, 443-458.http://www.animalsandsociety.org/wp-content/ uploads/2016/05/salamano.pdf (oct. 2018)

Schyff, G. (2014): Religious Slaughter and Religious Freedom in a Multilevel Europe: The Wider Importance of the Dutch Case. Oxford Journal of Law nad Religion 3(1), 76-102. https:// academic.oup.com/ojlr/article/3/1/76/1461692 (oct. 2018)

Shechita UK (2009): A Guide to Shechita. 3-13. https:// www.shechitauk.org/wp-content/uploads/2016/02/A_Guide_ to_Shechita_2009_01.pdf (oct.2018)

Szumigalska, A., M. Bazan (2014): Religious Slaughter Issue in Poland: Between Religious Freedom, Legal Order and Economicpolitical Interests. Religion and Society in Central and Eastern Europe 7 (1): 53-69. http://eds.b.ebscohost. com/eds/pdfviewer/pdfviewer?vid=0\&sid=7bf2f545-120e4b79-86b0-31462a895824\%40sessionmgr120 (oct. 2018)

The Law Library of Congress, Global Legal Research Center (2018): Legal Restrictions on Religious Slaughter in Europe. https://www.loc.gov/law/help/religious-slaughter/religious-slaughter-europe.pdf (oct. 2018)

Uršulin-Trstenjak, N., A. Dugonjić , D. Levanić, S. Šušnić , V. Šušnić (2015). The specifics of halal standard - HRN
BAS 1049:2010. Journal of Hygienic Engineering and Design. 66-70. Food Quality and Safety. Kakurinov, Vladimir - Skopje : Consulting and Training Centre http://www.jhed.mk/filemanager/JHED\%20Vol.\%2012/02.\%20FQS/06.\%20Natalija\%20 Ur\%C5\%A1ulin-Trstenjak.pdf (oct. 2018)

Velarde, A., P. Rodriguez, A. Dalmau, C. Fuentes, P. Llonch, K. V. von Holleben, M. H. Anil, J. B. Lambooij, H. Pleiter, T. Yesildere, B. T. Cenci-Goga (2014): Religious slaughter: Evaluation of current practices in selected countries. Meat Sci., 96 (1), 278-287. https://www.sciencedirect.com/ science/article/abs/pii/S0309174013003409 (oct. 2018)

Zivotofsky A. Z. (2011): Government Regulations of Shechita (Jewish Religious Slaughter) in the Twenty-First Century: Are They Ethical? Journal of Agricultural and Environmental Ethics 25(5), 747-763. https://link.springer.com/ article/10.1007/s10806-011-9324-4 (oct. 2018)

Zuolo, F. (2014): The Priority of Suffering Over Life. How to Accommodate Animal Welfare and Religious Slaughter. Les ateliers de l'éthique 3(9). 23 p. https://www.erudit.org/ en/journals/ateliers/2014-v9-n3-ateliers01748/1029064ar. pdf (oct. 2018)

Zuolo, F. (2015): Equality among animals and religious slaughter. Historical Social Research, 40(4), 110-127.http://eds.a.ebscohost.com/eds/pdfviewer/ pdfviewer?vid=0\&sid=3a9785b5-f80a-42ee-9284156951f9ad54\%40sessionmgr4009 (oct. 2018)

Deliveder: 17.10 .2018$.

Accepted: 1.12 .2018 .

\section{Religijjsko klanje u Europskoj uniji - kratki pregled}

\section{SAŽETAK}

Cilj ovog rada bio je razmotriti trenutne postupke religijskog klanja i dileme s kojima se suočava Europska unija. Omamljivanje životinja prije klanja zakonski je propisan zahtjev u EU kojemu je cilj izazivanje nesvijesti životinja kako klanje kod njih ne bi izazivalo tjeskobu, bol, patnju, ili stres. U nekim državama EU uvjetno je dozvoljeno religijsko klanje bez predhodnog omamljivanja, ili omaljivanjem odmah nakon iskrvanjenja. Životinje namijenjene religijskom klanju moraju biti zdrave i za vrijeme klanja neozlijeđene. Kako bi se ispunili ti zahtjevi, religijsko klanje provodi se isključivo u odobrenim i ovlaštenim klaonicama. Klanje mogu obavljati samo ovlaštene i posebno educirane osobe. U EU postoji mnogo dilema oko religijskog klanja, primjerice, uzorkuju li ove metode klanja dodatnu patnju kod životinja. lako muslimansko klanje u nekim slučajevima dopušta prethodno omamljivanje s određenim metodama, židovsko klanje nikada ne dopušta nikakav postupak omamljivanja. Stoga je važno nastaviti s ispitivanjem alternativnih načina omamljivanja koji će osigurati integritet živih životinja prije iskrvarenja. Istodobno je nužno uskladiti smjernice i postupke rukovanja sa životinjama prije i poslije klanja kao i certificiranje mesa iz vjerskog klanja kako bi se izbjeglo dovođenje potrošača u zabludu.

Ključne riječi: religijsko klanje, omamljivanje, EU 


\section{Religiöse Schlachtungen in der Europäischen Union - Kurze Übersicht}

\section{ZUSAMMENFASSUNG}

Ziel dieser Arbeit war es, die aktuellen Verfahren der religiösen Schlachtung und die Dilemmas in Erwägung zu ziehen, mit welchen die Europäische Union konfrontiert ist. Die Betäubung von Tieren stellt eine in der EU gesetzlich vorgeschriebene Forderung dar, welche sicherstellen sollte, dass das Tier bewusstlos ist, damit die Schlachtung keinen Stress, Schmerzen, Leiden oder UnwohI verursacht. Einige Länder der Europäischen Union lassen ausnahmsweise religiöse Schlachtungen ohne eine vorangehende Betäubung oder die Betäubung unmittelbar nach dem Halsschnitt zu. Die für religiöse Schlachtungen vorgesehenen Tiere müssen gesund und unversehrt sein. Um den Anforderungen gerecht zu werden, dürfen religiöse Schlachtungen ausschließlich in zugelassenen und ermächtigten Schlachthöfen stattfinden und nur durch berechtigte und speziell ausgebildete Personen durchgeführt werden. Die EU setzt sich mit zahlreichen Dilemmas in Zusammenhang mit religiösen Schlachtungen auseinander, z.B. rufen die Verfahren der religiösen Schlachtung ein zusätzliches Leiden bei Tieren hervor. Obwohl religiöse Schlachtungen im Islam den Einsatz bestimmter Betäubungsmethoden in einigen Fällen zulassen, ist im Judentum die Betäubung bei religiösen Schlachtungen keinesfalls zugelassen. Daher müssen alternative Betäubungsverfahren auch weiterhin geprüft werden, um die Integrität der Tiere vor dem Ausbluten sicherzustellen. Zugleich müssen die Richtlinien und Verfahren des Umgangs mit den Tieren vor der Schlachtung und danach sowie das Bescheinigungsverfahren, dass das Fleisch aus religiösen Schlachtungen gewonnen wurde, übereingestimmt werden, damit die Verbraucher nicht irregeführt werden.

Schlüsselwörter: religiöse Schlachtung, Betäubung, EU

\section{Matanza religiosa en Unión Europea - comunicación corta}

\section{RESUMEN}

El fin de este trabajo fue discutir los procedimientos actuales de la matanza religiosa y los dilemas con los que se enfrenta la Unión Europea. El aturdimiento de los animales antes de la matanza es un requisito prescrito por la ley de la UE y su fin es asegurar que el animal sea inconsciente para que la matanza no le cause la ansiedad, el dolor, el sufrimiento o el malestar. Algunos países de la Unión Europea permiten la excepción de la matanza religiosa sin aturdimiento previo o el aturdimiento inmediatamente después de la degollación. Los animales destinados a la matanza religiosa tienen que ser sanas y sin lesiones. Para cumplir con esos requisitos, las matanzas religiosas tienen lugar solamente en los mataderos autorizados y aprobados. La matanza religiosa pueden llevar a cabo únicamente las personas autorizadas y educadas. UE se está enfrentando con muchos dilemas en relación con la matanza religiosa, por ejemplo, si los procedimientos de la matanza religiosa causan el sufrimiento adicional a los animales. Aunque la matanza religiosa en islam permite en ciertos casos el uso de algunos métodos del aturdimiento previo, la matanza religiosa en judaísmo no permite el aturdimiento bajo ninguna circunstancia. Por eso es importante continuar con las investigaciones de las maneras alternativas del aturdimiento que asegurarían la integridad de los animales vivos antes del sangrado. Al mismo tiempo, es necesario armonizar las pautas y los procedimientos del manejo de los animales antes y después de la matanza y del certificado que la carne es de la matanza religiosa para evitar la desinformación de los consumidores.

Palabras claves: matanza religiosa, aturdimiento, UE

\section{Macellazione riltualle nell'Unione europea - Artlicolo di rassegina}

\section{RIASSUNTO}

Lo scopo di quest'articolo consiste nel riflettere sui procedimenti attuali finalizzati alla macellazione rituale e ai dilemmi con i quali si confronta I'Unione europea. Lo stordimento degli animali prima della loro macellazione rappresenta un requisito sancito dalla legge comunitaria il cui scopo è quello di garantire che l'animale, al momento della macellazione, sia privo di sensi affinché la macellazione non provochi in esso stress, dolore, sofferenza o disagio. Alcuni stati dell'Unione europea consentono eccezionalmente la macellazione rituale non preceduta dallo stordimento, oppure con lo stordimento immediatamente successivo allo sgozzamento. Gli animali destinati alla macellazione rituale devono essere sani e privi di ferite. Per soddisfare a detti requisiti, la macellazione rituale viene eseguita soltanto in macellerie abilitate e autorizzate. La macellazione rituale può essere eseguita soltanto da persone autorizzate e all'uopo abilitate. L'UE si confronta con numerosi dilemmi legati alla macellazione rituale, ad esempio se i procedimenti di macellazione rituale causino o meno ulteriore sofferenza negli animali. E mentre la macellazione rituale nella cultura islamica in determinati casi prevede l'utilizzo di alcuni metodi di stordimento preventivo, la macellazione rituale nella cultura giudaica non consente lo stordimento in nessun caso. È perciò importante proseguire nella ricerca di modalità alternative di stordimento che garantiscano l'integrità degli animali vivi prima che muoiano dissanguati. Nel contempo, è necessario armonizzare le direttive e i procedimenti di manipolazione degli animali prima e dopo la macellazione oltre ai certificati che attestano la provenienza della carne da macellazione rituale, al fine di evitare d'indurre il consumatore in errore.

Parole chiave: macellazione rituale, stordimento, UE 